\title{
Dramaturgi Ludruk Karya Budaya Mojokerto Jawa Timur Lakon Sarip Tambak Oso
}

\author{
Jihan Kusuma Wardhani \\ Institut KH Abdul Chalim Mojokerto \\ kusumajihan@gmail.com
}

\begin{abstract}
Abstrak
Dramaturgi Ludruk Karya Budaya Mojokerto-Jawa Timur pada Lakon Sarip Tambak Oso, adalah pengkajian teater rakyat yang orisinal oleh penulis. Ini merupakan penelitian yang menggunakan pendekatan kualitatif untuk mengetahui LKBM secara lebih mendalam melalui keilmuan dramaturgi. Kelompok ini telah bertahan lama, yaitu sekitar 48 tahun. Cerita STO telah hidup lebih lama dari pada kelompok LKBM. Ludruk telah menjadi hiburan khas Jawa Timur, dan cerita STO adalah salah satu legenda yang terus hidup di masyarakat Jawa Timur, khususnya Sidoarjo. Cerita STO sangat dekat dengan masyarakat dan konflik dalam lakon merupakan hal yang sering terjadi di masyarakat sehingga cerita ini mengingatkan betapa pentingnya komunikasi yang baik antara pemerintah dan masyarakat. Kebaruan penelitian ini adalah sampai saat ini belum ada yang melakukan penelitian secara kajian dramaturgi terhadap LKBM khususnya pada lakon STO. Lakon yang menceritakan tentang perjuangan hak seorang manusia yang bernama Sarip yang tidak mau membayar pajak karena kemiskinannya. Hal itu menimbulkan perlawanan terhadap pemerintahan Belanda dan antek-anteknya, hingga akhirnya kelemahan Sarip dicari agar dapat membunuhnya yaitu dengan membungkam teriakan sang Ibu agar tidak bisa membangunkan Sarip dari kematiannya. Cerita ini dianggap nyata oleh sebagian masyarakat yang ada di Wilayah Jawa Timur, khususnya di daerah Sidoarjo tepatnya di wilayah Tambak Oso. Seiring perkembangannya cerita ini kemudian menjadi pembelajaran bagi masyarakat setempat untuk lebih bijak menyikapi segala keputusan yang telah ditentukan pemerintah. Baik itu antara pemerintah dan rakyat hendaknya sama-sama melakukan komunikasi yang tepat agar tercipta keharmonisan. Melihat banyaknya terjadi mis komunikasi antara pemerintah dan rakyat dalam mengambil kebijakan. Kajian dramaturgi LKBM pada lakon STO diharapkan mampu menjadi pembelajaran baik itu ludruk sebagai kelompok kesenian rakyat, maupun ceritanya yang bisa menjadi pengetahuan bagi masyarakat.
\end{abstract}

Kata kunci: dramaturgi; LKBM, STO, teater rakyat, tontonan

Abstract
Dramaturgi Ludruk Mojokerto-East Java Cultural Work on Sarip Tambak Oso, is
an original study of folk theater by the author. This is a study that uses a qualitative
approach to find out LKBM in more depth through dramaturgy science. This group


has been around for a long time, which is around 48 years. The STO story has outlived the LKBM group. Ludruk has become a typical entertainment in East Java, and the STO story is one of the legends that continues to live in the people of East Java, especially Sidoarjo. STO's story is very close to the community and conflict in the play is something that often happens in the community so this story reminds us of the importance of good communication between the government and the community. The novelty of this research is that until now no one has conducted a study on dramaturgy studies on LKBM especially in the STO play. A play that tells about the struggle for the rights of a human being named Sarip who does not want to pay taxes because of his poverty. This gave rise to resistance to the Dutch government and its accomplices, until finally Sarip's weakness was sought in order to kill him, namely by silencing his mother's shout so he could not wake Sarip from his death. This story is considered real by some people in the East Java Region, especially in the Sidoarjo area, precisely in the Oso Pond area. As the development of this story became a lesson for the local community to wisely respond to all decisions determined by the government. Whether it is between the government and the people, they should share the right communication to create harmony. Seeing how much happens is communication between the government and the people in taking policies. The dramaturgy study of LKBM in the STO play is expected to be able to become good learning as a folk art group, as well as a story that can become knowledge for the community.

Keywords: dramaturgy; LKBM, STO, folk theater; performance

\section{PENDAHULUAN}

Ludruk Karya Budaya Mojokerto (LKBM) merupakan salah satu kelompok ludruk yang cukup produktif dan menarik untuk diteliti. Hal itu disertai oleh alasan empiris dengan melihat begitu banyaknya kelompok-kelompok ludruk yang ada di Jawa Timur yang telah gulung tikar. Sebagai kelompok yang cukup tua di Jawa Timur, yaitu berdiri sejak 29 Mei 1969 (Susanto, 2014:34), LKBM mampu memberikan contoh semangat dan perjuangan bertahan untuk menjalankan kesenian rakyat yang ada di Jawa Timur. Banyak kelompok ludruk yang gagap atau tidak siap menghadapi pesatnya perkembangan arus globalisasi, baik itu teknologi maupun informasi saat ini, bahkan ludruk dianggap tidak mampu mengikuti perkembangan zaman dan tidak bisa membaca situasi dan kondisi (Kasemin, 1999:117). Namun LKBM yang kini berada di usia 47 tahun masih eksis di belantika hiburan kesenian rakyat.

Kelompok ini diperkuat dengan adanya pengelolaan yang baik, keanggotaan yang solid dan disiplin, dan kualitas keanggotaan yang telah diakui oleh masyarakat. Peneliti menilai bertahannya kelompok LKBM juga didukung oleh banyak aspek yang senantiasa dikembangkan dan dipatuhi oleh setiap anggotanya. Oleh sebab itu peneliti merasa bahwa LKBM pantas untuk diangkat sebagai objek penelitin. Selain itu dalam pementasan LKBM ini juga banyak tanda-tanda yang bisa ditafsirkan. Peneliti berharap agar apa yang dilakukan oleh LKBM ini bisa menjadi inspirasi, baik itu bagi diri peneliti sendiri, 
orang lain, dan kelompok ludruk yang ada di Indonesia.

Mengapa pentingnya melakukan penelitian dramaturgi, karena dalam pengkajian teks drama dan kajian teori dramaturgi cukup lengkap dalam pembahasannya, sebab dramaturgi sebagai pendekatan perlu kiranya dikembangkan fungsinya untuk membaca pertunjukan (Yudiaryani, 2015:58). Lebih jauh Barba menjelaskan:

My dramaturgy was also a method to find something I wasn't looking for. At the start of a new performance, there were tacit knowledge and dark forces: a certain degree of artisanal skill, a dialogue with that part of me which lived in exile, revolt and unbelieving prayer. In practice, my dramaturgy established different types of collaboration: of one actor with another, of the actors with the director, and of the actors and director with the spectator (Barba, 2010: 205).

Dalam pembacaan dramaturgi tentulah tidak terlepas dari tanda-tanda yang ada di dalam pertunjukan oleh sebab itu penulis menggunakan teori semiotika, karena ilmu semiotika relevan untuk membaca dan menafsirkan suatu teks, baik itu mengungkap ikon, tanda, pesan, makna, pertanda dan halhal yang terkait di dalam ludruk yang banyak memberikan pesan tersirat dan tersurat. Pesan tersirat seperti misalnya terdapat dalam teksteks maupun sindirian yang biasanya di lontarkan dalam ludruk, sementara pesan tersurat adalah yang bisa dilihat oleh penonton.

Ludruk merupakan suatu bentuk kesenian rakyat yang ada di Indonesia, khususnya di wilayah Jawa Timur. meskipun mengalami pasang surut dalam perkembangannya, namun ludruk memiliki nilai pendidikan dan hiburan yang cukup besar dalam lingkup kesenian Indonesia. Kasim Ahmad mengatakan bahwa kesenian ludruk berasal dari Jombang, yaitu ketika seorang bernama Pak Santik di desa Ceweng, Kecamatan Jombang, yang mempunyai sifat humoris dan lucu, yang didesak oleh kebutuhan hidup. Ia berkeliling seorang diri sambil menari dan bernyanyi dan sedikit berceritera, lalu memperoleh uang untuk kegiatannya itu, dan disinilah lahir apa yang disebut Lerok Barangan, suatu bentuk ludruk yang mula-mula dan dilakukan seorang diri. Dalam perkembangannya ada juga yang disebut dengan Ludruk Garingan, yaitu ludruk yang dimainkan seorang diri dengan tidak diiringi oleh tetabuhan apapun (Ahmad, 2006: 151-152).

Sementara Peacock seorang peneliti ludruk yang berasal dari Amerika mengatakan bahwa pertunjukan-pertunjukan yang disebut sebagai ludruk bandan dan ludruk lyrok telah ada sejak lama, yaitu sejak zaman kerajaan Majapahit abad XIII di Jawa, namun saksi mata pertama yang menonton pertunjukan yang disebut ludruk itu baru ia temukan secara tertulis pada tahun 1882. Pertunjukan ludruk dalam tulisan tersebut dilukiskan dibintangi oleh dua orang, yakni seorang pemain dagelan, yang bercerita tentang cerita-cerita lucu, dan seorang waria (Peacock, 1968:28).

Banyak yang mencoba melacak tentang asal-asul kelahiran ludruk ini namun tidak ada kepastian tentang awal kelahirannya, peneliti untuk saat ini mengumpulkan pendapat para peneliti sebelumnya berdasarkan hasil 
penelitian Kasemin (1999) yang menyatakan dalam manuskrip berjudul Babat Ranu Grati yang dibuat sekitar abad 17 terdapat kata ludruk yang berarti Badhut. Namun jika ditelusuri lebih jauh lagi kata Badhut itu sendiri telah ada pada abad ke 8 , terbukti dari data sejarah kerajaan Karuyuhan di mana candi peninggalannya dinamakan candi Badhut (Kasemin, 1999:113).

Ludruk mengalami penurunan minat oleh masyarakat saat ini khususnya Jawa Timur. Sepinya minat masyarakat tentang ludruk saat ini dapat dibuktikan pada sepinya gedung ludruk di Taman Hiburan Rakyat (THR) Surabaya dan kini telah beralih fungsi menjadi tempat diskotik (Kasemin, 199:2). Ironis memang, kesenian yang dulunya sempat berjaya dan digandrungi oleh masyarakat pada zamannya, kini harus berjuang di tengahtengah zaman teknologi dan modernisasi.

Adapun upaya untuk terus melestarikan ludruk salah satunya ialah terus menggali elemen yang terdapat di dalam ludruk kemudian menuliskannya sebagai warisan untuk anak bangsa. membahas dramaturgi ludruk menjadi penting sebab dengan adanya ilmu dramaturgi ludruk generasi kedepan akan memperoleh titik terang tentang pelbagai keilmuan yang bisa digunakan dalam membaca pertunjukan ludruk.

Menurut Eugenio Barba, dramaturgi adalah kajian teater yang digunakan untuk membicarakan teater sebagai pertunjukan daripada teater sebagai "kelanjutan" naskah drama. Barba menyebut teater sebagai teks. Kata teks berasal dari kata tekstur yang berarti "rajutan bersama". Dramaturgi dalam hal ini adalah ilmu tentang teks, dramaturgi tekstual. Dalam pengertian ini, tidak ada pertunjukan yang hadir tanpa rajutan bersama, tanpa teks. Konkretnya, pertunjukan teater adalah aksi teaterikal yang terkait dengan dramaturgi (Yudiaryani, 2015:58).

Pasang surutnya eksistensi ludruk juga tidak terlepas dari kreativitas para pelakunya yang sampai saat ini timbul dan tenggelam muncul di permukaan ludruk, baik itu masih eksis dari sejak berdirinya maupun yang benar-benar sudah tidak pernah menjadi pemain ludruk lagi. Satu dari sekian banyak kelompok ludruk yang terdapat di Jawa Timur yang terus eksis hingga kini ialah kelompok Ludruk Karya Budaya Mojokerto (berikutnya disingkat LKBM). Kelompok ludruk ini berdiri semenjak tahun 1969, tepatnya empat tahun setelah terjadinya peristiwa G30S PKI di negeri ini.

Peneliti telah menyeleksi beberapa karya andalan dari LKBM yang bisa dijadikan sampel untuk membuat dramaturgi ludruk. Salah satu karya andalan dari LKBM yaitu lakon "Sarip Tambak Oso" (berikutnya disingkat STO). Lakon STO merupakan salah satu karya dari LKBM yang dokumentasinya telah dikomersilkan di pasaran sejak tahun 2009. Karya ini mengangkat cerita rakyat yang berasal dari Sidoarjo dan LKBM telah berhasil mengemas pertunjukan ini dengan sangat memadai. Baik itu dari segi audio maupun visual, keaktoran, penyutradaraan, lawakan, tarian dan gendingannya. Maka dari itu, lakon STO akan dijadikan sebagai sampel untuk mengkaji dramaturgi ludruk.

Selain itu naskah STO termasuk naskah populer di masyarakat dan juga bagi kelompok ludruk yang ada di Jawa Timur, sebab sikap dan perlawanan Sarip merupakan bentuk perlawanan terhadap ketidakadilan. Bangsa 
Indonesia adalah bangsa yang berdiri sendiri dan ingin berdaulat, tetapi mengapa Belanda selalu berada di Indonesia dengan menguras hasil bumi dan pajak rakyat (Kasemin, 1999:86). Itulah sebabnya mengapa STO dijadikan sebagai simbol perjuangan rakyat kecil dan rata-rata masyarakat yang ada di Jawa Timur sangat menyukai lakon STO ini.

\section{HASIL DAN PEMBAHASAN}

Eugene Barba mendefinisikan dramaturgi sebagai akumulasi aksi yang tidak terbatas pada gerakan-gerakan aktor, tetapi juga meliputi aksi-aksi yang terkait dengan adegan-adegan, musik, cahaya, vokal aktor, efek suara, dan objek-objek yang dipergunakan dalam pertunjukan (Barba dalam Sahid, 2004:4). Lebih jauh dikatakan oleh Barba bahwa dramaturgi hanya bisa diidentifikasi dari suatu teks tertulis otonom (teks drama) dan proses pertunjukan teater yang melibatkan para karakter (Sahid, 2004:4). kajian dramaturgi memungkinkan untuk mengkaji semua unsur yang terdapat dalam peristiwa pertunjukan. Namun konteks yang akan dilakukan dalam kajian ini ialah hanya mengkaji elemen terpenting saja dari dramaturgi lakon STO LKBM, baik itu dalam pementasannya yang saling berkaitan antara peristiwa pertunjukan, tempat dan penonton, maupun elemen yang terkandung didalamnya, seperti hubungan antara aktor, sutradara, naskah lakon, tempat dan penonton.

Berdasarkan kutipan di atas, peneliti merumuskan bahwa kerja dramaturgi Barba sesuai dan bisa dilakukan sebab di dalam pementasan lakon STO juga memuat hal-hal seperti yang ada di dalam dramaturgi Barba. Misalnya Barba menciptakan tarian antara aktor dan penonton untuk membiarkan pengalaman merasuki mereka, sebagai titik balik dari hubungan dengan diri mereka sendiri (Barba, 2010: 205). Pementasan STO memuat unsur tari, musik dan seni akting, yang secara tidak langsung membuat penonton akan memiliki pengalaman tersendiri ketika menyaksikannya, artinya seorang penonton tidak menutup kemungkinan juga seorang dramaturg.

Agar analisis dramaturgi pementasan lakon STO LKBM ini lebih sistematis dan terarah, maka unsur-unsur dramaturgi pementasan lakon STO LKBM ini akan digali bersamaan secara struktrur dan tekstur pertunjukan. Kernodle mengatakan bahwa nilai-nilai dramatik karya teater mencakup plot, tokoh, tema yang disebut sebagai struktur, dialog, mood (suasana hati atau musik), dan spektakel merupakan unsur tekstur (Sahid, 2013: 30). Pada saat menganalisis struktur dan tekstur inilah seluruh unsur dramaturgi pementasan lakon STO LKBM akan diterapkan.

Bila diurutkan, plot yang terdapat dalam pementasan ludruk lakon STO LKBM terdapat empat babak, atau dalam bahasa ludruknya disebut juga dengan babakan. yang pertama ialah remo, kemudian dilanjutkan dengan bedayan, setelah itu lawak, dan yang terakhir ialah lakon sebagai puncak dari perhelatan ludruk. pada bagian ludruk peneliti menggunakan istilah Robert Longeworth yang membagi plot dramatik sebagai sebuah lakon dengan a) eksposisi, b) penggawatan tahap pertama, c) penggawatan tahap kedua, d) klimaks, e) penyelesaian (Satoto, 2012: 45).

plot yang ada pada lakon STO dimualai dari pengenalan awal (eksposisi) lakon STO 
menyajikan peristiwa pelarian STO di tengah hutan yang dikejar-kejar oleh Mantri Polisi utusan Belanda dan para Lurah yang menjadi antek-antek Belanda. Saat berlari STO meninggalkan sarungnya di tengah hutan, sampai Lurah Tambak Oso (LTO) masuk menemukan dan mengenakan sarung STO. LTO menggunakan sarung tersebut untuk menyelimuti badannya dan kemudian tidur. Mantri Polisi sudah berbangga hati menemukan STO yang bersembunyi di dalam sarung, namun saat akan dibunuh ternyata LTO yang terbangun dengan terkejut dan penangkapan STO dinyatakan belum berhasil. Pengenalan awal tersebut disambung dengan adegan MP yang memberi perintah kepada LNG untuk menangkap STO. LTO dianggap tidak mampu untuk mengatur penduduknya, akibat kebiasaannya yang sering mencari istri baru. MP beserta para anak buah dan antekanteknya mengadakan rapat mendadak untuk memutuskan menindak STO. MP yang mengatasnamakan Government kemudian menawarkan kepada LNG, apabila ia bisa menangkap STO, maka ia akan diberi hadiah. Melalui eksposisi lakon STO, maka dapat diketahui bahwa salah satu tujuan pokok pemerintah Belanda ialah untuk merencanakan penangkapan STO karena tidak mau membayar pajak.

Pengggawatan tahap pertama. Pada tahapan ini muncul konflik antar tokoh, meskipun sesungguhnya saat dimulainya adegan, penonton sudah disuguhkan dengan adegan konflik. pada tahapan ini, konflik terjadi antara STO dengan LNG. Sebelum konflik antara LNG dan STO terjadi, LTO lebih dulu mendatangi rumah STO dengan maksud awal ingin memperingatkan STO karena telah membuat pemerintah marah. Kedatangan LTO ke rumah STO ternyata diselipi oleh nafsu yang berpura-pura baik pada IS, tapi menawarkan ingin memadu. Konflik batin dari IS bisa dirasakan pada adegan ini. LTO merayu dengan memburu nafsu, maksud baik LTO ternyata berbuntut pamrih yang mengharapkan IS agar mau dimadu. Keteguhan hati sang IS membuat LTO mengurungkan niatnya, Ia pun pergi, .hingga akhirnya LNG datang Datangnya LNG tidak dengan masuk baik. Ia mengancam dan menggertak IS, baik itu menanyakan keberadaan STO, maupun meminta pajak pada IS. Pada saat IS mengatakan tidak memiliki uang, bukan rasa kasihan yang ia berikan melainkan hardikan yang kemudian dilanjut dengan ancaman clurit untuk membunuh IS. Saat sang ibu sedih karena merasa ditindas, STO datang membela sang ibu, namun STO masih tenang dan menanyakan kepada LNG tentang perlakuan kasar terhadap ibunya. Kesombongan LNG yang menagih pajak pada STO serta ingin membunuh akhirnya mendapatkan perlawanan dari STO. Perkelahian terjadi dan pada bagian ini LNG mati di tangan STO atas kesombongannya sendiri. Berdasarkan dari analisis bagian ini dapat diketahui bahwa ternyata pembangkangan STO yang tidak mau membayar pajak, menjadi sumber konflik antar tokoh pada penggawatan cerita tahap pertama.

Pada penggawatan tahap kedua ini konflik cerita bertambah naik, pada tahap pertama konflik terjadi antara LNG dengan IS dan STO dengan LNG. Konflik tersebut terjadi karena ketidakmauan STO membayar pajak sebab ia memang hidup dalam kemiskinan. 
Sikap LNG yang cendrung memaksa akhirnya membuat ia meregang nyawa. Konflik pada penggawatan tahap dua terjadi antara STO dan Paidi, karena kata-kata Paidi yang menghina serta menuduh STO sebagai maling. STO membantah dan mengatakan bahwa ia bukan maling. STO membela diri, tidak membayar pajak bukan berarti menjadi maling. kemiskinan dan keadaan menyebabkan ia tidak sanggup membayar pajak. Perdebatan antara Paidi dan STO di mulai pada ketersinggungan STO saat dikatakan sudah bukan orang Jawa lagi, hingga akhirnya perdebatan tersebut berujung pada perkelahian.

Penggawatan cerita (klimaks) memasuki puncaknya pada babak ke-8 adegan ke-1 yang sekaligus klimaks dari pertunjukan lakon STO LKBM. Klimaks cerita di bangun dari konflik yang intens saat STO berhadapan dengan para Lurah yang berusaha ingin membunuhnya. Seorang Paidi yang merasa pendekar setempat juga ikut ambil bagian untuk menguji kanuragannya menghadapi STO. Perkelahian pertama memang Paidi menang, bahkan membuat STO tewas. Namun kekuatan STO ada pada IS. Apabila IS berteriak memanggil nama STO, maka STO akan hidup lagi. Hidupnya STO akhirnya membuat ia menuntut balas pada Paidi, sebab Paidi telah berhutang nyawa pada STO yang telah berhasil membunuhnya. Bagi STO, hutang nyawa di bayar nyawa, sampai akhirnya STO berhasil membalas kematiannya dengan membunuh Paidi. Hal ini pula yang membuat MP marah besar, karena sudah banyak yang menjadi korban atas perbuatan STO. Oleh karena itu kelemahan STO diupayakan oleh para Polisi, hingga akhirnya ketegasan untuk mempertanyakan riwayat hidup STO ditanyakan pada LTO. Usulan untuk mendatangkan saudara STO yaitu Mualim ialah berasal dari LTO. sampai kemudian diketahuilah kelemahan STO, yaitu dengan menahan IS untuk tidak berteriak saat STO ditembak dengan peluru emas yang dioles minyak babi.

Dalam lakon STO LKBM penyelesaian masih terdapat pada babak ke-8 adegan ke-1. Penurunan plot cerita menuju tahap penyelesaian, setelah konfli-konflik yang memuncak tajam sampai menyebabkan kematian pada tokoh STO. Akhirnya cerita diakhiri dengan nasehat Mualim sebagai kakak Sarip terhadap IS, agar merelakan dan mengikhlaskan meninggalnya STO. Kepolosan dan keluguan IS membuat ia tidak bisa berbuat apa-apa. Padahal jika IS berteriak, maka STO akan hidup kembali dan tentu saja akan menjadi petaka bagi MP. Pada tahap penyelesaian ini juga MP turut mengancam IS agar tidak berteriak.

Berikutnya pembahasan pada penokohan. Penokohan merupakan suatu usaha yang dilakukan oleh aktor untuk membedakan peran satu dengan peran yang lain. Perbedaan-perbedaan peran ini diharapkan akan diidentifikasi oleh penonton (Santosa, 2008: 90). Jika proses identifikasi berhasil dilakukan oleh seorang aktor, maka penonton akan merasa terwakili oleh perasaan peran yang diidentifikasi tersebut. Penokohan sering juga disebut dengan seni peran yakni, seorang manusia yang bisa memainkan tokoh dengan dirinya dan menghidupkan perasaanperasaan tokoh dalam aksinya. Hakikat seni peran adalah meyakinkan (Riantiarno, 2003: 45). 
Dalam lakon STO LKBM ini terdapat 17 tokoh yang saling berkaitan satu sama lain. Beberapa di antaranya terdapat berpasangan, misalnya Sarip Tambak Oso (STO) dan IS/IS (IS), Mualim dan Istri Mualim (IM), Mantri Polisi (MP), Lurah Sedati (LS), Lurah Sedayu (LSY), Lurah Noto Gedangan (LNG), Opas 1 dan Opas 2, Penjaga Warung (PW), Fatimah, Gadis 1 dan Gadis 2. Paidi dan Saropah, Selanjutnya yang sendiri, Lurah Tambak Oso (LTO).

Dalam suatu pementasan teater, terutama teater rakyat dan teater tradisi manapun, dibutuhkan adanya tokoh yang berperan di dalamnya yang disebut dengan sebutan aktor, terutama dalam lakon-lakon ludruk. Secara struktur narasi pada lakon STO, tokoh dominan di naskah tersebut adalah STO sebagai tokoh utama. Akan tetapi dalam lakon STO ini banyak mengalami kontradiksi yang berbeda apabila mengkaji penokohannya melalui kaca mata keilmuan Barat. Terutama persoalan pembagian tentang karakter tokoh antagonis, protagonis dan tritagonis. Dalam bahasa ludruk peran disebut dengan rol, ada rol alus (protagonis) dan rol kasar (antagonis). Tokoh yang ada di dalam ludruk terutama lakon STO lebih mengupayakan sebagai contoh terhadap masyarakat agar tidak menjadi budak penjajahan pada masa itu.

Tokoh protagonis selalu identik dengan tokoh baik, sementara pada kenyataanya tokoh STO adalah seorang pembunuh yang dianggap meresahkan pemerintahan Belanda. Begitu juga dengan tokoh MP dan Mualim yang dianggap baik, secara identifikasi tokoh, tetapi kontradiktif karena telah membantu Belanda untuk membunuh STO yang tidak mau membayar pajak. Dalam hal ini bagi pihak pribumi, Mualim justru menjadi antagonis karena telah bersekutu dengan Belanda pada saat itu. Sedangkan ibu yang seharusnya menjadi tokoh tritagonis, justru tidak bisa berbuat apa-apa saat anaknya STO mati di tembak Belanda. Secara keseluruhan berdasarkan kajian penokohan di atas tampak penokohan lakon STO memiliki perwatakan yang paradoks, berhubung tokoh yang dihadirkan tersebut adalah simbol yang harus di baca oleh penonton dan saling memiliki relasi serta kerterkaitan satu sama lain.

Tema adalah rumusan tentang inti suatu cerita (Tambajong, 1981: 24). Artinya pada tema kemudian dibeberkan maksud dan keinginan pengarang agar bisa menjadi patokan cerita. Tema juga bisa menjadi persoalan pokok pada cerita, misalnya masalah pendidikan, persahabatan, dan lainlain (Riantiarno, 2011: 78). Pada tema kemudian naskah cerita akan berkembang dan fokus dalam pemabahasannya. Tema adalah ide sentral (pokok) yang dapat terungkapkan, baik secara langsung maupun tidak langsung Artinya tema merupakan ide atau pikiran utama di dalam karya sastra, baik itu tersirat, maupun tersurat (Satoto, 2012: 40).

\section{Relasi Antarunsur dalam Lakon STO}

Dalam keterkaitan antar relasi yang terdapat di dalam analisis struktur yang telah dipaparkan sebelumnya, baik itu plot, penokohan dan tema, maka dalam analisis ini akan dibahas hubungan antar relasi tersebut. Tema yang menjadi pikiran dasar dari cerita telah tampak mengembangkan konflik sedemikian rupa, dan penokohan juga begulir dalam pertentangan antara protagonis dan 
antagonis. Penokohan yang terdapat dalam lakon STO LKBM ini lengkap, di mana masing-masing tokoh yang ada memiliki ciri dan karakternya masing-masing. Pada intinya bila diklasifikasi tokoh-tokoh yang hadir di dalam lakon STO, hidup dengan dualisme pemahaman yang dipercaya oleh masyarakat Indonesia. Seperti kerja alam, ada panas, ada dingin, ada langit, ada bumi dan seterusnya. Maka begitulah dalam lakon STO.

Penokohan yang tampak ialah golongan kaya dan miskin, golongan abangan dan santri, meskipun tidak secara frontal dihadirkan. Tokoh Mualim yang santri bertentangan dengan tokoh STO yang abangan, begitu juga para Lurah yang menjadi momok menakutkan di dalam masyarakatnya. MP yang menjadi penguasa di Tambak Oso menjadi sosok menakutkan oleh masyarakatnya. Adapun relasi yang menghubungkan antar unsur yang terdapat pada struktur lakon STO salah satunya ialah dialog dari masing-masing tokoh yang tampak sudah menjadi karakter dalam menghidupkan plot menjadi dramatik.

Tokoh dengan tema sangat terkait satu sama lain, jelas tema kemiskinan sebagai cara bertahan hidup akhirnya membuat manusia mencari jalan untuk bertahan hidup. Selama tidak bersalah dan demi membela diri terpaksa harus membunuh, itulah yang dialami oleh STO. Jika saja STO adalah orang kaya maka tidak akan terjadi konflik dalam plot cerita ini. Tema yang juga adalah pokok pikiran plot cerita menjadi jelas, bahwa hidupnya plot lakon STO ini berkat tema yang berbicara tentang konteks kemiskinan tokoh STO.

Keserasian yang membentuk kesatuan terjalin antara plot, penokohan dan tema, karena memang lakon STO itu sendiri berangkat dari folklore, namun penghadirannya berangkat dari peristiwa sehari-hari. Plot lakon STO itu sendiri memang sudah konvensional. Seperti yang dikatakan oleh Soemanto (2002: 43) bahwa lakon konvensional, sudah memiliki acuan di luar teks, yakni kenyataan sehari-hari dan menekankan bahasa verbal sebagai medium utama untuk berkomunikasi. Bila diamati lebih jeli lagi maka benar bahwa lakon STO LKBM ialah bermedium bahasa verbal sebagai komunikasinya dan juga bahasa sehari-hari, khususnya bahasa sehari-hari masyarakat Jawa Timur, baik itu untuk menyampaikan tema, menjalankan plot dan menghidupkan masing-masing tokoh secara karakter dan perwatakannya.

Tidak ada yang menjadi lebih fokus antara ketiga unsur yang terdapat di dalam lakon STO LKBM ini. Semuanya saling menguntungkan satu sama lain dan saling melengkapi, sebab tema bisa diketahui dari penokohan, dan dari plot bisa dirasakan perkembangan cerita dari awal hingga akhir. Pemahaman terhadap ketiga unsur antara plot, penokohan dan tema dalam lakon STO LKBM ini menciptakan keutuhan dalam struktur lakon STO.

Setelah melakukan tahap analisis seperti di atas, maka dapat diambil suatu kejelasan bahwa relasi yang terkait antar tema dengan penokohan dan plot STO menjadi berarti. Perwatakan tokoh STO dan IS, bertentangan dengan perwatakan MP, Mualim, LNG, LS, LSY, Opas 1, dan Opas 2. Hal inilah yang kemudian mengembangkan tema, dan akibatnya konflik yang terjadi antar tokoh yang berlainan perwatakan dan sikap hidup, 
menyebabkan plot dramatik menjadi berkembang dalam beberapa struktur dramatik hingga akhir cerita. Plot, penokohan dan tema tampak saling berkaitan satu sama lain.

Tema cerita telah menginspirasi lahirnya tokoh-tokoh protagonist dan antagonis yang memiliki sikap dan perwatakan yang bertentangan. Secara dramaturgi, relasi yang terdapat pada plot, penokohan, dan tema kemudian dirumuskan dalam wujud dialog yang telah membentuk lakon STO menjadi karya drama yang mencerminkan adanya kesatuan dan keserasian antar unsur. Pemahaman tema STO tidak dapat dilepaskan dengan pemahaman unsur plot dan penokohan. Begitu juga sebaliknya, pemahaman terhadap plot dan penokohan STO tidak dapat dilepaskan dengan unsur yang ada pada tema.

Secara dramaturgi relasi ketiga unsur plot, penokohan dan tema cukup selaras dan seimbang, sebab tidak ada unsur yang mendominasi satu sama lain. Tema drama STO tidak berdiri sendiri sebagai unsur yang mendominasi dibandingkan dengan penokohan dan plot cerita. Begitu pula, unsur penokohan maupun plot STO tidak lebih dominan dibandingkan dengan yang lain. Plot, penokohan dan tema saling membentuk suatu kesatuan yang utuh dan menciptakan keharmonisan yang serasi.

Pembahasan segala unsur tentang struktur sama pentingnya dengan pembahasan segala unsur tentang tekstur. Unsur yang terdapat dalam struktur di antaranya plot, penokohan dan tema. Sementara unsur yang terdapat dalam tekstur ialah dialog, suasana dan spektakel. Tekstur menurut Kernodle dalam (Sahid, 2013) merupakan segala sesuatu yang secara langsung dapat di lihat, di dengar, dan dirasakan sebagai mood (suasana hati) melalui keseluruhan pengalaman visual dan aural. Sedangkan tekstur menurut Barba ialah, anyaman pertunjukan dari elemen pertunjukan yang mencakup drama, penyturadaraan, pemeranan, spektakel, bahkan penonton (Sahid, 2013: 34).

Dalam drama, cakapan yang terjadi antara dua orang tokoh atau lebih disebut dialog (dialoque) (Satoto, 2012: 59). Dialog dalam lakon merupakan sumber utama untuk menggali segala informasi tekstual. Di samping itu, pada eksekusi (pelaksanaan pentas), dialog menjadikan teks tertulis terdengar, perwatakan (characterization) tokoh menampak-diri, wujud masalah teraba oleh kegiatan aktif menikmati pentas (Soemanto, 2002: 42). Kutipan yang disampaikan oleh Bakdi Soemanto ini kemudian akan dijadikan acuan untuk penelitian tekstur lakon STO LKBM. Karena teks lakon tidak memiliki narasi, jalan dan perkembangan peristiwa dalam lakon hanya dapat di teliti melalui dialog-dialog.

Suasana adalah salah satu faktor pendukung dalam lakon maupun pementasan teater, begitu juga dengan lakon STO LKBM. Menonton pertunjukan lakon STO LKBM secara tidak langsung telah menghadirkan suasana yang beraneka ragam, sehingga penonton bisa merasakan suasana tersebut. Misalnya saja pada saat pementasan STO berlangsung, telah di mulai dengan suasana yang menegangkan saat para Polisi ingin menangkap tokoh STO. Begitu juga selanjutnya, suasana pertunjukan terus menanjak seiring plot cerita, baik itu ke suasana tenang kemudian dilanjutkan ke 
suasana yang tegang, puncak dari ketegangan dalam lakon STO LKBM ialah dengan terjadinya pembunuhan yang dilakukan oleh STO dan MP.

Suasana yang terbangun dalam ludruk, mendapat istilah tersendiri dari pelaku ludruk yaitu, menggunakan konsep kendo kenceng. Artinya ialah konsep pengadeganan longgar dan rapat yang intinya, adegan tenang, riang dan tegang saling bergantian mengisi pementasan ludruk hingga mencapai puncak klimaks. Suasana ceria atau riang yang terdapat pada adegan warung di saat Supali dan pelayannya masuk. Suasana keharmonisan antara anak dan ibu bisa dirasakan ketika adegan STO yang betapa cinta terhadap ibunya. Begitu juga dengan suasana yang penuh curiga antara Lurah Gedangan ketika mencari STO. Juga suasana ketegangan saat STO membunuh Paidi. Dalam lakon STO bisa dirasakan betapa kompleks suasana pengadeganan, tanpa terasa penonton menikmati pertunjukan sampai selesai.

Spektakel adalah kesan dalam sebuah pertunjukan yang sengaja dirancang di atas panggung untuk disuguhkan kepada penonton sebagai penguat adegan, baik itu secara audio maupun visual. Pertunjukan tanpa spektakel sudah pasti akan sangat membosankan, oleh sebab itu dengan adanya spektakel diharap karya pentas yang dihasilkan bisa memberi daya pukau terhadap penonton. Bahkan Aristoteles menyatakan, bahwa spektakel merupakan nilai terakhir dalam puitika pertunjukan. Stanilavsky menyebut bahwa inner akting seorang aktor sebagai sumbangan terbesar sebuah pertunjukan, sebaliknya Graig dan Appia menganggap, bahwa melalui spektakel pertunjukan akan mampu dinikmati oleh penonton (Yudiaryani, 2002: 363). Berikut ini merupakan contoh adegan yang dalam lakon STO yang membuat unsur tekstur

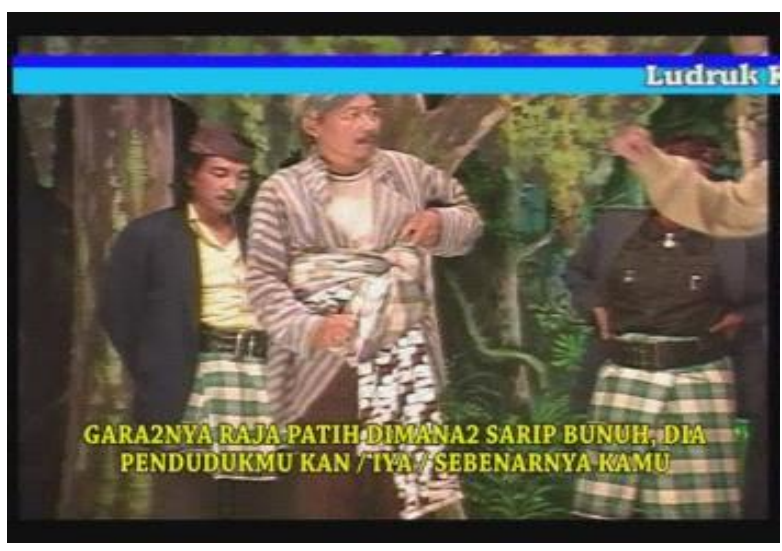

Gambar 1. Adegan LTO saat dimarahi oleh MP (foto koleksi LKBM, tahun 2009)

Adegan diatas adalah gambar adegan kedua babak 1 lakon STO. penjelasannya ialah layar yang di buka kembali, lokasi masih di dalam hutan dan dengan iringan musik yang meninggi, suasana emakin menegang dari sebelumnya disebabkan pelarian STO. Lampu berwarna hijau, berkelip-kelip dengan kombinasi putih seperti kilat menjadi spektakel dalam adegan ini, diiringi oleh gerak laku kekawatiran STO yang panik dan takut tertangkap oleh utusan Belanda. Spektakel adalah ruang visual yang dapat disimbolkan melalui suara atau unsur pemanggungan lainnya (Yudiaryani, 2002: 364). Nampak STO berlari dan tanpa sengaja menjatuhkan kain sarung yang dikenakannya, sarung itu bermotif kotak-kotak besar berwarna cokelat dan putih. Tanpa menghiraukan sarungnya, STO terus berlari untuk menghindari kejaran para Polisi dan Lurah.

Setelah STO menghilang, masuklah tokoh baru. Ia seorang lelaki yang agak tua, memakai baju sorjan Jawatimuran berwarna coklat, bercelana coklat, melilitkan jarit 
dipinggangnya, dan memakai blangkon Jawatimuran, dialah LTO. suasana sedikit mengendor dan menjadi rileks disebabkan sosok LTO yang telah akrab dikenal penonton sebagai pelawak handal, sehingga apapun wujud pemanggungan yang ia bawakan selalu berkecenderungan kepada humor. LTO berjalan santai dan menemukan sarung tergeletak di jalan, ia pun mengambil serta memakaikannya di badannya.

Setelah itu masuklah LS, LSY, dan dua Opas Polisi. Ketika mereka melihat ada orang tergeletak di jalan, mereka berhenti, terjadi dialog mempertanyakan bahwa sarung yang dikenakan STO benar dipakai oleh orang yang tidur. Mereka mengira bahwa yang tidur tergeletak di jalan ialah STO. Saat ingin membunuh sosok di dalam sarung tiba-tiba mereka terkejut karena sosok yang ada di dalam sarung adalah LTO. Suasana yang tadinya menegang menjadi terpatah beralih ke lucu (konyol) sebab orang yang ada di dalam sarung bukanlah STO melainkan LTO yang memang membawakan karakter lucu.

\section{Mantri Polisi :}

jogoen, tak bedile, ojo sampek gak mati! Tak tembake Sarip, tak pasne, siji ... loro ... telu ... (saat hampir menembak) / berjagalah, biar aku tembak, jangan sampai tidak mati! biar ku tembak Sarip, aku tepatkan, satu... dua... tiga

LTO :

(terbangun sambil membuka sarungnya) eh eh eh ... / eh eh eh

Mantri Polisi : lah kok Lurah Tambak Oso? (heran) / lah kok Lurah Tambak Oso?

LTO : nggeh kulo e / iya saya

Mantri Polisi : heh? / heh?

LTO :

kulo. / saya
Setelah diketahui bahwa yang MP temui ialah LTO, ia kemudian memarahi LTO akan tanggungjawabnya sebagai Lurah di daerah Tambak Oso karena dianggap tidak becus mengurus warganya. Suasana menjadi kaku kembali, dan LTO tak mampu membantah kata-kata MP, sebab ia menyadari bahwa MP memiliki kuasa di daerah Sidoarjo. setelah itu dipanggillah LNG yang selanjutnya diberi perintah dari MP untuk menangkap STO. Jika berhasil menangkap STO, maka akan diberi hadiah oleh pemerintah Belanda. Setelah itu LTO berjalan ke bibir panggung, namun tak sampai keluar panggung. Ia melambaikan tangannya seperti mengisyaratkan seseorang untuk masuk.

Disadari atau tidak pada akhirnya semua yang tampak di dalam pertunjukan teater merupakan tanda, baik itu tanda tersirat maupun tanda tersurat. Tanda tersirat ialah seperti audio yang bisa memberikan efek-efek tertentu bagi penonton, sementara tanda tersurat bisa hal verbal dan visual. Umumnya tanda bersifat trans-individual sehingga akan dapat dipahami oleh orang banyak. Akan tetapi, ada juga tanda yang bersifat individual. Tanda dalam hal ini baru dapat berfungsi jika telah di interpretasi (interpretant). Interpretant bukanlah orang yang memberikan interpretasi, melainkan pemahaman makna yang timbul dalam diri si penerima (Yuliadi, 2005: 14).

Tanda dalam teater di produksi oleh aktivitas para aktor, linguistik, paralinguistik, musikal, mimik, gestural, and proxemic sign denote the corresponding cultural sign. Seperti yang dikatakan oleh Lichte (1992) dalam bukunya yang menyatakan: 
We need to know the function and effect they have in culture as a whole if we are to be in a position to study them with respect to their specific function and effect in theater. Thus, it would appear meaningful to draw on a semiotics of language, musik, mimicry, gestur, and proxemic movement (Lichte, 1992: 16).

Lakon STO LKBM sarat akan tanda, sehingga analisis semiotika yang digunakan ialah tiga belas sistem tanda yang telah dirumuskan oleh Tadeusz Kowzan yaitu: tanda kata, nada, mime, gestur, gerak, make-up, gaya rambut, kostum, property, setting, lighting, musik dan sound effect.

Berikut ini merupakan salah satu contoh gambar dalam adegan 1 babak 1 yang memuat unsur-unsur makna yang bisa disingkap dengan 13 sistem tanda Tadeusz Kowzan.

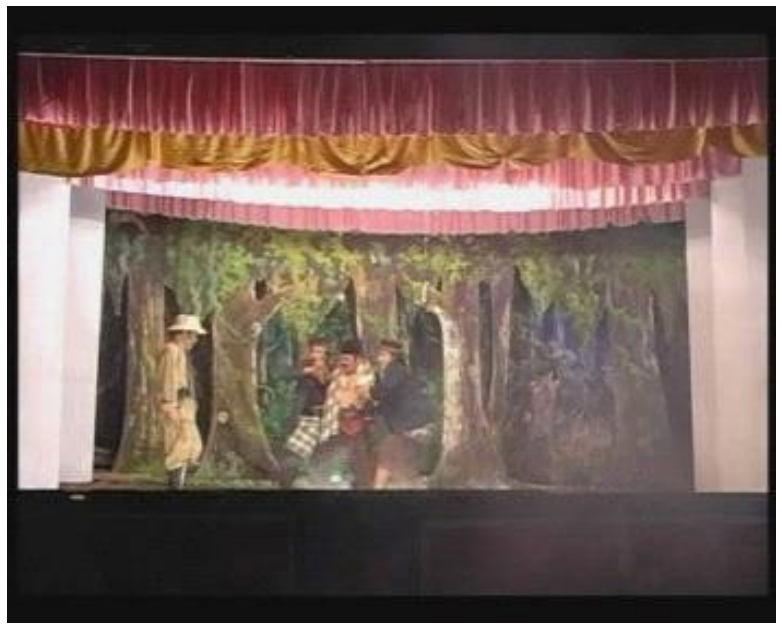

Gambar 2. Setting babak 1 lakon STO LKBM (foto koleksi LKBM, tahun 2009)

Adegan tersebut dimulai dengan layar yang terbuka, diringi oleh bunyi petasan sebagai gimmick awal. Musik mengalun menanjak dengan nuansa kendang yang dipercepat dengan semakin keras. Nampak asap putih mengepul di atas panggung sebagai pembangun suspen dan menjadi penanda ketegangan adegan. Pada adegan ini ialah peristiwa pengejaran STO (diperankan oleh Mujiono/Mujed). Tempat kejadian berada di hutan belantara yang ditandai oleh penataan setting yang menggambarkan hutan, baik itu layar sebagai backdrop, maupun beberapa tumbuhan yang dihadirkan sebagai penguat kehadiran realitas hutan. Adapun gambaran setting dari masing-masing adegan dalam lakon STO ini berganti-ganti disetiap pembabakannya.

Setting yang digunakan seluruhnya berdasarkan layar yang dilukis untuk menggambarkan tempat terjadinya peristiwa. Seperti adegan pertama setting bergambar hutan saat para Polisi dan Lurah ingin menangkap STO. Mencekamnya adegan pembuka sebagai gimmick memberikan kesan yang memukau, sehingga adegan pertama ini cukup kuat kehadirannya sebagai eksposisi dan tokoh STO tampak kuat menjadi penanda sumber konflik dalam cerita.

Keadaan berubah menjadi mencekam yang juga ditandai dengan musik yang menegang dengan tempo dipercepat. Musik yang mengiringi-pun menghentak kecang sebagai penanda ketegangan yang memperkuat suasana. Para aktor yang beraksi di atas panggung bisa diidentifikasi melalui kostumnya. Seorang lelaki berpakaian hitam dan berpeci hitam berlarian dengan panik (penanda). Keadaan mencekam didukung dengan musik tegang dan efek asap mengepul di sekitarnya (petanda). Lelaki itu ialah Sarip Tambak Oso (STO). Berikutnya menyusul dua orang lelaki yang sama-sama berpakaian hitam, mereka mengejar dan berhasil mencengkeram tangan STO dengan kasar. 
Mereka berdua ialah Lurah Sedati (diperankan oleh Sukariyono) dan Lurah Sedayu (diperankan oleh Dumaji). Kemudian disusul dengan seorang lelaki lagi. Ia berpakaian seperti seorang Polisi dan bertingkah senior, berpakaian warna krem, berdasi biru, bertopi putih, memakai sepatu boots hitam dan membawa pistol sebagai petanda kekuasaan atas jabatan yang dimilikinya, dialah Mantri Polisi/MP (diperankan oleh Karsani). Pada zaman STO bisa diperkirakan bahwa tidak sembarang orang yang bisa memiliki pistol. Pistol juga sebagai penanda untuk memperkuat karakter yang diusung tokoh yang membawanya. Bahkan pada zaman sekarangpun pistol menjadi penanda kekuasaan oleh para pemiliknya, faktanya bisa di lihat bahwa banyak oknum pejabat pemerintahan di negeri ini yang menjadikan senjata pistol sebagai alat kekuasaan untuk mengakhiri nyawa seseorang, seperti kasus penembakan yang dilakukan oleh aparat pemerintah seperti TNI dan Polri terhadap Mahasiswa dalam kasus 21 mei 1998 di Jakarta.

Pementasan lakon STO juga memberikan tanda pengenalan tersendiri pada kostum, akan tetapi kostum yang menjadi tanda dalam ludruk sudah bisa dibaca dan ditebak oleh para penonton, karena atribut yang dipakai para aktor mudah ditandai. Pada intinya kostum yang dikenakan dalam pementasan STO mencoba menghadirkan sesuai dalam kehidupan realitas, meskipun dibeberapa sisi terdapat variasi yang sengaja ditempelkan oleh aktor secara improvisasi, misalnya dasi yang terdapat pada kostum MP kecuali pada remo dan bedayan. Artinya dengan merepresentasikan kostum berdasarkan realitas membuat penonton lebih mudah menandai peran dan fungsi tokoh dalam lakon STO.

Mantri Polisi atau lebih diartikan sebagai pimpinan para Polisi, dan terakhir tokoh yang datang berjumlah dua orang lelaki lagi, berpakaian Opas Polisi juga. Mereka berpakaian warna krem dan bertopi coklat, serta membawa senapan angin. Ketika Mantri Polisi telah mendekati STO, STO melawan dan berhasil melarikan diri lagi. Mantri Polisi marah dan menumpahkan seluruh kekesalannya pada bawahannya, termasuk kepada dua Lurah yang ada di hadapannya. Lampu berubah hijau, berkelip-kelip kombinasi putih seperti kilat, sebagai tanda ketegangan untuk mendukung aksi aktor dalam menciptakan dramatik. Adegan ini seakan memperlihatkan pada penonton bahwa kekuasaan berada di tangan orang-orang yang memegang senjata, seperti MP dan para lurah, menjadi tanda manusia yang berkuasa dan bisa bertindak semena-mena. Kemudian layar ditutup.

\section{KESIMPULAN}

Berdasarkan uraian yang telah disampaikan, pada bab kesimpulan ini penulis mencoba menarik makna pertunjukan lakon STO LKBM sebagaimana yang telah dilakukan di atas memberikan pesan secara tersirat yang bisa dirasakan bagi penonton yang berfikir, bahwa dengan kematian STO justru membuat Ia mendapatkan kemerdekaan yang diinginkannya, dengan kematian, ia tidak perlu lagi membayar pajak, dan kematian STO tentu saja menimbulkan semangat baru bagi penontonnya yang cerdas. Secara tidak langsung buah dari lahirnya STO yang baru 
ialah dengan lahirnya semangat para pemuda Indonesia khususnya Sidoarjo untuk bersamasama berjuang mempertahankan kemerdekaan yang telah berhasil di raih dan dikumandangkan bersama pada tanggal 17-81945.

Proklamasi kemerdekaan dibacakan oleh pimpinan pertama Indonesia yaitu Presiden Soekarno dan Wakil Presiden pertama Mohammad Hatta. Sepanjang pertunjukan, permasalahan tentang STO selalu muncul menjadi pembahasan, baik dalam fungsinya sebagai pengantar cerita yang menentukan garis nasib, maupun sebagai tokoh utama yang menjadi pesan, tanda, dan makna. Jelas bahwa tokoh STO menentukan jalannya alur, sehingga dengan banyaknya kehadiran konflik tentang STO baik itu dari diri STO maupun tokoh yang lain, merupakan sebuah penanda yang terkait dengan makna pertunjukan secara keseluruhan. Maksudnya STO sebagai tokoh mengacu kepada makna perjuangan rakyat kecil untuk melawan ketidakadilan pemerintah yakni penjajahan Belanda. Kemunculan STO sebagai sosok pejuang kecil semakin mempertegas hal itu.

Kenyataannya banyak rakyat kecil yang tidak menjadi perhatian pemerintah, hanya yang punya kedudukan saja yang memiliki relasi dengan pemerintah Belanda. Penegakkan hukum hanya berhasil diterapkan untuk rakyat kecil, akan tetapi tidak berlaku bagi pihak-pihak yang lebih berkuasa, apalagi yang menjadi antek-antek dari penjajahan Belanda itu sendiri. Melalui lakon STO, LKBM mencoba menyuarakan isi hati rakyat kecil yang kurang mendapat perhatian dan bantuan pemerintah di negeri ini. Justru yang berani melawan akan berhadapan dengan kematian sebagai buronan, pengalaman ini banyak terjadi pada saat berkuasanya suatu rezim di negeri ini yakni rezim penjajahan Belanda dan rezim Orde Baru.

Dengan demikian makna lakon STO LKBM ini memiliki pandangan yang futuristik. Makna yang terkandung tidak hanya kontekstual dengan kondisi historis pada zaman penjajahan Belanda, akan tetapi saat lakon STO ini di pentaskan. Sampai dengan saat ini bahkan beberapa tahun yang akan datang, makna lakon STO LKBM ini akan terus kontekstual di Indonesia. Bahwasannya yang berkuasa di dalam jejaring pemerintah adalah sistem feodalis dan oligarki yang dipimpin oleh sekelompok orang yang menjadi hegemoni. Seolah-olah yang dekat dengan pemerintahlah yang akan selamat.

\section{DAFTAR PUSTAKA}

Acmad, A. Kasim. (2006). Mengenal Teater Tradisional di Indonesia. Jakarta: Dewan Kesenian Jakarta.

Barba, Eugenio. (2010). On Directing And Dramaturgy, Burning The House. New York: The Taylor \& Rancis eLibrary.

Kasemin, Kasiyanto. (1999). Ludruk Sebagai Teater Sosial, Kajian Kritis Terhadap Kehidupan, Peran Dan Fungsi Ludruk Sebagai Media Komunikasi. Surabaya: Airlangga University Press.

Lichte, Erika Fischer. (1983). The Semiotics Of Theatre. By Gunter Narr Verlag, Tubingen. Translated by Jeremy Gaines \& Doris L. Jones. 1992. Indiana: Indiana University Press. 
Peacock, James L. (1968). Ritus Modernisasi Aspek Sosial dan Simbolik Teater Rakyat Indonesia, Depok: Penerbit Desantara.

Riantiarno, Nano. (2011). Kitab Teater, Tanya Jawab Seputar Seni Pertunjukan. Jakarta: PT.Gramedia Widia Sarana Indonesia.

Sahid, Nur. (2004). Semiotika Teater. Yogyakarta: Lembaga Penelitian Institut Seni Indonesia Yogyakarta.

Sahid, Nur. (2013). Estetika Teater Gandrik Yogyakarta Era Orde Baru Kajian Sosiologi Seni. Yogyakarta: Badan Penerbit Institut Seni Indonesia Yogyakarta.

Santoso, Eko dkk. (2008). Seni Teater Jilid 1 untuk Sekolah Menengah Kejuruan. Jakarta: Direktorat Pembinaan Sekolah Menengah Kejuruan, Direktorat Jenderal Manajemen Pendidikan Dasar dan Menengah, Departemen Pendidikan Nasional.

Satoto, Soediro. (2012). Analisis Drama Dan Teater. Yogyakarta: Ombak.

Soemanto, Bakdi. (2002). Godot Di Amerika Dan Indonesia, Suatu Studi Banding. Jakarta: Grasindo.

Tambajong, Japi. (1981). Dasar-dasar Dramaturgi, Drama Sebagai Sastra, Drama Sebagai Seni Aktor, Sutradara, Estetik, Kritik, Penonton. Bandung: Pustaka Prima.

Yudiaryani. (2002). Panggung Teater Dunia Perkembangan dan Perubahan Konvensi. Yogyakarta: Pustaka Gondho Suli.
Yudiaryani. (2015). WS Rendra dan Teater Mini Kata. Yogyakarta: Galang Pustaka.

Yuliadi, Koes. (2005). Drama Gong Bali. Yogyakarta: BP ISI Yogyakarta. 